\title{
Edyta Abramek
}

University of Economics in Katowice

e-mail: edyta.abramek@ue.katowice.pl

\section{VALUE GENERATED BY SOCIAL NETWORKS IN THE CONTEXT OF METCALFE'S LAW}

WARTOŚĆ GENEROWANA PRZEZ SIECI SPOLECZNE
W KONTEKŚCIE PRAWA METCALFE'A

DOI: $10.15611 /$ ie.2017.4.01

JEL Classification: A13, C31, D85, I21

Summary: The topic of this article is network analysis, shown as an activating method used in education. Due to a growing interest in social networking sites and an increased importance of cooperation, it is necessary to improve students' skills in the field of methods provided by Social Network Analysis (SNA). The potential of social networks can be used, for example to develop contacts, share ideas and as a communication tool. The aim of this paper is to present how students can study "network effects" - the value generated by network structures. This issue will be clarified on the example of Metcalfe's law, selected measures of the SNA method and others. The exercise presented in the article is an excellent base for conducting in-depth research using the SNA method, which in turn allows to identify barriers to the flow of knowledge, discover invisible structures and relationships, analyse the collected data quantitatively and qualitatively. The article will indicate directions of using the analysis of social networks in research works at universities.

Keywords: Metcalfe's law, social graph, social media, Social Network Analysis, SNA.

Streszczenie: Tematem artykułu jest analiza sieciowa, ukazana jako metoda aktywizująca stosowana w dydaktyce. Ze względu na rosnące zainteresowanie serwisami społecznościowymi i wzrost znaczenia współpracy konieczne jest doskonalenie umiejętności studentów w zakresie metod, jakich dostarcza analiza sieci społecznościowych (SNA). Potencjał sieci społecznościowych może zostać wykorzystany na przykład do rozwijania kontaktów, dzielenia się pomysłami i jako narzędzie komunikacji. Celem artykułu jest przedstawienie, w jaki sposób studenci mogą badać tzw. efekty sieciowe - wartość, jaką generują struktury sieciowe. Kwestia ta zostanie wyjaśniona m.in. na przykładzie prawa Metcalfe'a. Ćwiczenie zaprezentowane $\mathrm{w}$ artykule stanowi doskonałą bazę do prowadzenia dlaszych badań z wykorzystaniem metody SNA, która z kolei pozwala identyfikować bariery w przepływie wiedzy, odkrywać niewidoczne struktury i relacje, analizować zgromadzone dane ilościowo i jakościowo. W artykule wskazane zostaną także kierunki wykorzystania analizy sieci społecznościowych w pracach badawczych na uczelniach.

Słowa kluczowe: prawo Metcalfe'a, graf społecznościowy, media społeczne, analiza sieci społecznych, SNA. 
Edyta Abramek

\section{Introduction}

Due to the search for new research methods and growing interest in social networking sites, the importance of network analysis as a research method will increase. Thus, there is a need to familiarize students with its capabilities and the IT tools that support it.

The network analysis is not a new phenomenon. However, it is still gaining importance:

- firstly, due to the growing popularity of social networking sites,

- secondly, due to the development of computer programs e.g. Gephi, Pajek, UCINET, NetDraw that allow the analysis of network graphs using mathematical and statistical methods. They also allow to visualise the network in graphical form.

\section{Related works}

The purpose of this paper is to present the use of Metcalfe's law in the analysis of the value of a network structure. This law is an excellent starting point for discussions about the value of social networks as part of didactic classes with students, which was presented on the example carried out in this paper. The term "Metcalfe's law" was first used by G. Gilder in 1993. R. Metcalfe studied the benefits of creating communications network, where the nodes of the network are computers or users of the World Wide Web. The idea is that a network is more valuable when more people you can call or write to or more web pages you can link to. According to Metcalfe, the network value refers to the number of its nodes $\left(n^{2}\right)$. The attempts to measure the value of the network were also made by: D. Sarnoff (the value of the broadcasting/ television network is proportional to the number of viewers), D. Reed (every new person on a network doubles its value, $2^{n}$ ), B. Briscoe, A. Odlyzko, B. Tilly (this value will be proportional to $n * \log (n)$ ), G. Zipf (if network has $n$ members, this value will be proportional to $1+1 / 2+1 / 3+\ldots+1 /(n-1)$, which approaches $\log (n))$ [Beckstörm 2008; Briscoe, Odlyzko, Tilly 2006; Czetwertyński 2013; Van Howe 2014]. Previous models of network value focused on the number of nodes or on the architecture or structure of the network, and more on the number of connections between network nodes. According to A. Kemper "the size of the customer network is a factor that determines its value to other adopters as the membership of an individual increases the benefits of other network members" [Kemper 2010]. According to R. Beckström, "the value of the network increases as more users join, bringing more transactions to the network. The more potential transactions a network has to offer, the more users will be attracted to it. The more users are attracted, the more valuable the network becomes" [Beckström 2008].

In summary, the value of the network can be measured by the value of its participants or connections. The involvement of participants is crucial for the value of network. On the other hand, the value of links consists not only of the existence of link between nodes (exchange occurrences), but also the so-called reciprocity (mutual exchange). Networks perceived from the perspective of these features i.e.: 
commitment, exchange and reciprocity in the economic practice take the form of coexistence, cooperation, coopetition or competition [Czakon 2009; Klimas 2015]. The literature on the subject defines different types of network effects [Unold 2011]: direct, indirect, inter-network and social.

\section{Social networks and social graphs}

Typical communities are created on the Internet around social networking sites, portals and blogs. There are a lot of reasons to create networks, such as: the need for contact, common interests, the desire to share their experiences, ideas. A person in their life belongs to a variety of networks: a network of friends, their family network, a network of people from work, a network of people with common interests and so on. The potential of the network in business is used, for example: to develop contacts, to build brand image, to share ideas and as a communication tool. The network is presented in a graph form when:

1. We evaluate the maturity of the organization. In Table 1 we can see the selected maturity levels of organizations and their typical structure.

Table 1. Maturity of the organization

\begin{tabular}{|c|c|c|}
\hline Level of maturity & Graphs & Characteristics \\
\hline DECENTRALIZED & & $\begin{array}{l}\text { No department manages or } \\
\text { coordinates any social activities }\end{array}$ \\
\hline CENTRALIZED & & One department manages all social activities \\
\hline HUB \& SPOKE & & $\begin{array}{l}\text { A cross-functional team sits in a centralized } \\
\text { position and helps various nodes }\end{array}$ \\
\hline $\begin{array}{l}\text { MULTIPLE HUB \& } \\
\text { SPOKE (DANDELION) }\end{array}$ & & $\begin{array}{l}\text { Similar to HUB \& SPOKE but applicable } \\
\text { to multinational companies }\end{array}$ \\
\hline HOLISTIC & & Everyone in the company uses social media \\
\hline
\end{tabular}

Source: based on [Owyang et al. 2010].

2. When we evaluate communication in the organization. In Table 2 we can see how the network analysis has improved communication in a team. 
Table 2. Communication in the organization

\begin{tabular}{|l|c|}
\hline Communication in a team & Graphs \\
\hline BEFORE & \\
\hline AFTER &
\end{tabular}

Source: based on [Pentland 2012].

3. When we compare how people work together. In Table 3 we can see how the organization looked during the crisis, and after fixing the situation.

Table 3. Communication in the organization

\begin{tabular}{|l|l|l|}
\hline Communication between teams & \multicolumn{1}{|c|}{ Characteristics } \\
\hline BEFORE & $\begin{array}{l}\text { Poor cooperation } \\
\text { between people from } \\
\text { the same department }\end{array}$ \\
\hline AFTER & $\begin{array}{l}\text { Strong collaboration } \\
\text { among people from } \\
\text { the same department }\end{array}$ \\
\hline
\end{tabular}

Source: based on [Stokalski 2007].

4. When we analyse how people communicate with each other. Literature distinguishes three types of network contacts (Table 4).

Table 4. Social network configurations

\begin{tabular}{|l|l|l|}
\hline Communication between teams & Network connections & \multicolumn{1}{|c|}{ Characteristics } \\
\hline Customized Response & $\begin{array}{l}\text { Network is dense and redundant, } \\
\text { both internally and externally }\end{array}$ \\
\hline Modular Response & $\begin{array}{l}\text { Network is focused on roles through } \\
\text { which different parties can rotate; } \\
\text { external connections are targeted } \\
\text { to inform aspects of response }\end{array}$ \\
\hline Routine Response & $\begin{array}{l}\text { Network is focused on process flow; } \\
\text { external connections are limited }\end{array}$ \\
\hline
\end{tabular}

Source: based on [Cross, Liedtka, Weiss 2005]. 
We present the network as a graph if we want to analyse it using the SNA (Social Network Analysis) method. The SNA method allows us to examine the network at three levels:

- at the macro-level - when we study the entire network,

- at the meso-level - when we examine selected parts of the network,

- and at the micro-level - when we analyse the network from the perspective of a single node.

\section{Research methodology}

Social networking sites open a new dimension in the relationships between organisations and their consumers, because they allow to build relationships with existing and new customers by integrating them into an interactive dialogue with the brand but also with each other.

Social networking sites are a source of valuable data about behaviour, preferences, needs and relationships of people today. It is widely believed that social software is the better the more people use it, but initiatives that create social networks can also take a toll on people. Unproductive relations mean that people lose their time or energy. That is why it is so important for people to learn how to promote connectivity only where it is beneficial, especially because the essence of the social relations graph are not only interpersonal relationships - nodes in a social graph can also be objects, places, points in time, etc. Therefore, the main thesis of the paper is that due to the growing interest in social networks, and especially social networking sites, the importance of the Social Network Analysis as a research method will grow. How can we familiarize students with its capabilities and the IT tools that support it?

The first research question can be formulated as follows:

RQ1: What is the value of the social network graph? Is the value of the network growing when we add more people?

The Metcalfe's law (Table 5) is a good explanation of things which are power and value of the social graph. This law was originally used for telecommunication networks. With regard to social network its verification was required. Thus, this law has been verified by D. Reed (Table 5) and others. Within the context of social networks many scientists, including Metcalfe himself, have proposed modified models using $n * \log (n)$ proportionality rather than $n^{2}$ proportionality.

Table 5. The Metcalfe's and Reed's laws

\begin{tabular}{|l|l|l|}
\hline Metcalfe's law & $\begin{array}{l}n^{2} \\
n-\text { the number } \\
\text { of participants }\end{array}$ & $\begin{array}{l}\text { The value (or the usefulness) of a telecommunication } \\
\text { network is proportional to the square of the number } \\
\text { of connected users of the system }\left(n^{2}\right) .\end{array}$ \\
\hline Reed's law & $\begin{array}{l}2^{n} \\
n-\text { the number } \\
\text { of participants }\end{array}$ & $\begin{array}{l}\text { The utility of large networks, particularly social networks, } \\
\text { can scale exponentially }\left(2^{n}\right) \text { with the size of the network. }\end{array}$ \\
\hline
\end{tabular}

Source: [Evans 2010]. 
The next research question is formulated in a following way:

RQ2: Which law, Metcalfe's or Reed's, is closer to the social network built by students in classes?

In order to obtain an answer to research questions formulated in such a way, an experiment was carried out.

\section{Social Network Analysis as a trend in education}

The experiment using social networks was originally described by C. Shih in the book "The Facebook Era" [Shih 2012]. It was first conducted by the Stanford Graduate School of Business.

During the classes students were divided into several teams. On the A4 sheets of paper they drew a circle, and marked their place on it (a point on the circle). They signed it with their name. Then each student wrote their request next to their name, for example: "I need a math book", "I need coffee", "I am looking for a job", "I need someone to pick me up at the train station", etc. Everybody was acquainted with the needs of others and if he or she could help, they drew an arrow pointing to that person (Fig. 1).

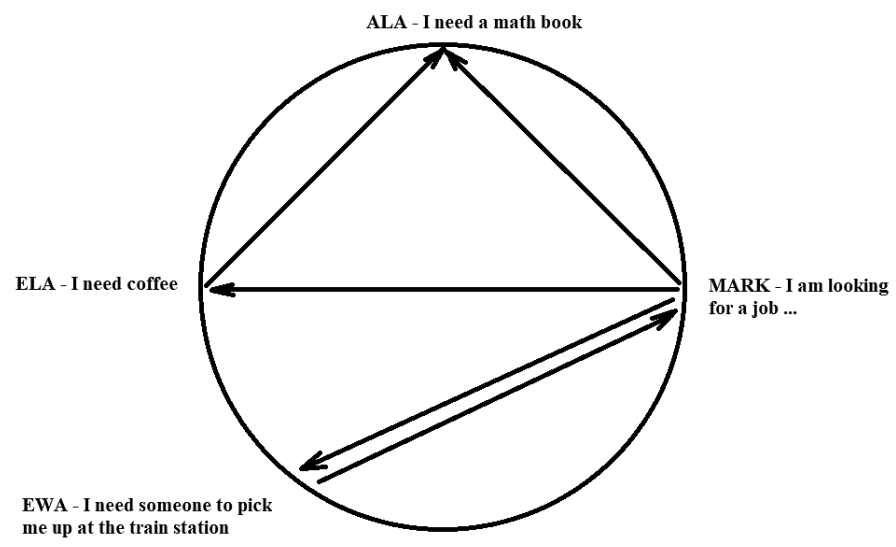

Fig. 1. An example of the social graph created by students

Source: author's own study.

In addition, students had to answer the following questions:

1 . Was there the answer for each request?

2. Was each student able to do at least one request?

3 . Were there two students who helped each other?

4. How many connections were made?

5 . What was the density of the network?

6. How many mutual exchanges were there? 
After the first stage of the experiment, 2-3 new members, which were previously inactive, were added to each team. The experiment and calculations were performed again from the beginning.

In summary, this research took the following steps:

1. Testing hypotheses by doing an experiment.

2. Analysing data and drawing a conclusion.

3. Presenting results.

\section{Experiment results and recommendations}

As a result of the study, empirical material was collected as a basis for further analysis. There are some conclusions:

1. According to the conducted experiment, it was found that the value of the network grew slower (Fig. 2, Fig. 3) than it was envisaged by Metcalfe $\left(n^{2}\right)$ or Reed's $\left(2^{n}\right)$ law .

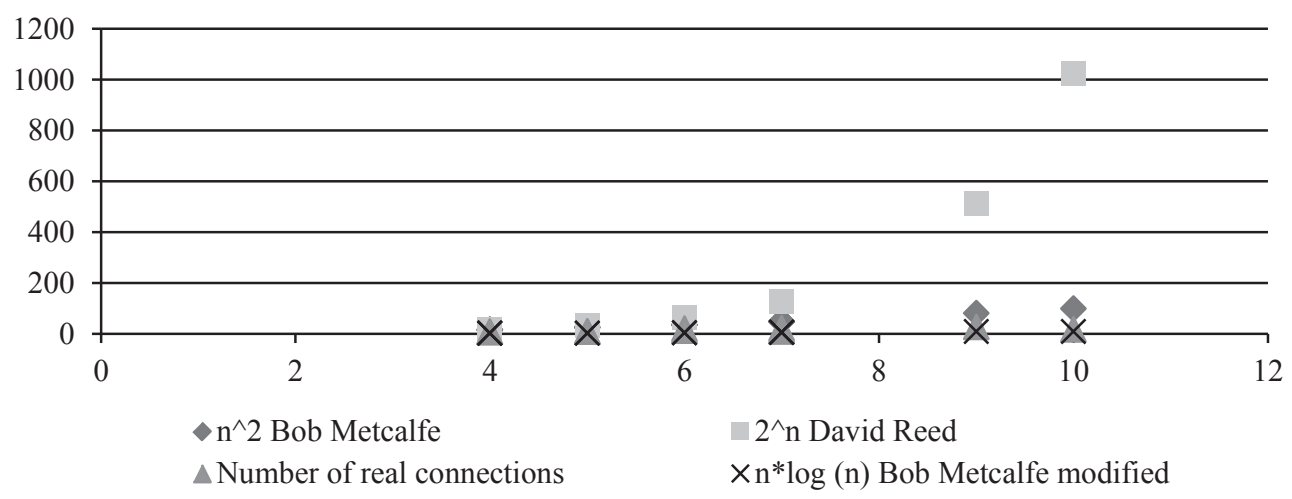

Fig. 2. Results of the experiment

Source: own study.

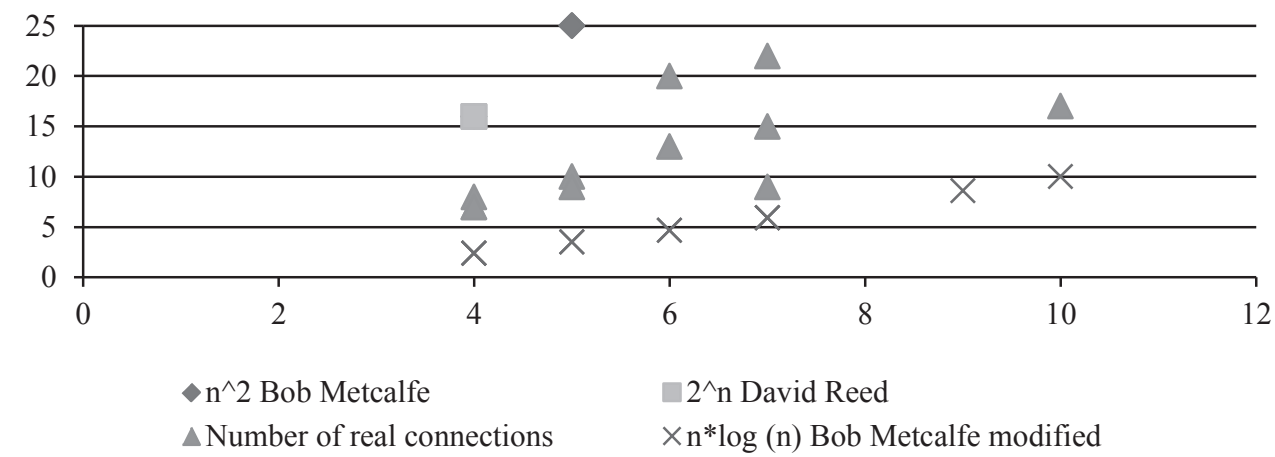

Fig. 3. Results of the experiment - in detail

Source: own study. 
2. It was noticed that adding new people to the network not always caused an increase in its density. Density is the relation of active connections (those that occur) to all possible in a given network [Ehrlich, Carboni 2005; Furht (ed.) 2010]. It is a simple but fundamental index from which we can start to analyse the structure present in a network. Density is an indication of homogeneity of the group and actors' engagements to each other [Martino, Spoto 2006]. In the three of sixth analysed networks, the density decreased with the increase of the attached persons (Fig. 4).
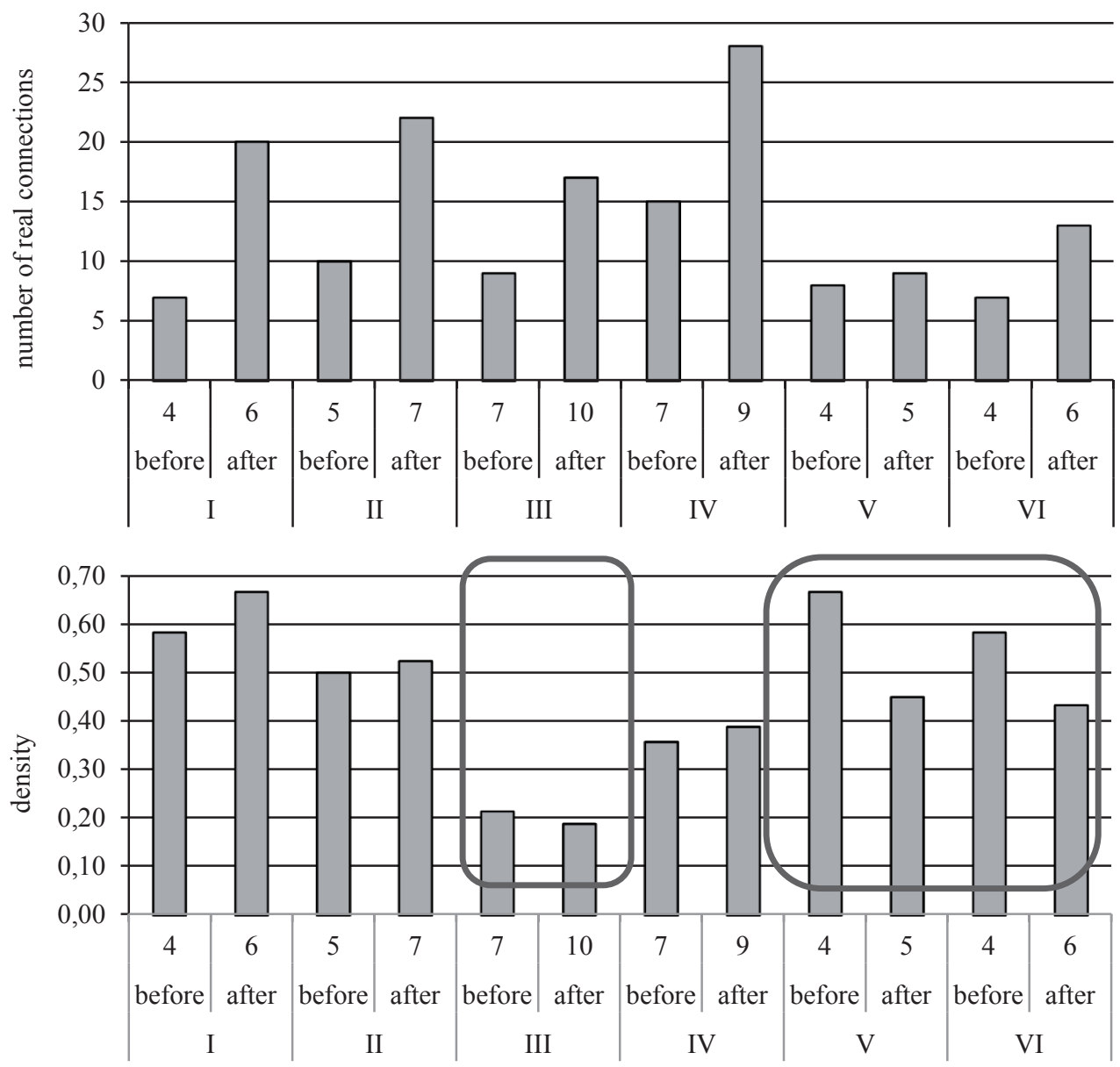

Fig. 4. Results of the experiment - the results of six teams (I-VI)

Source: own study.

3. Examining the network at the macro-level (by analysing the whole network) does not allow to grasp why although the number of nodes is growing, the density is decreasing. Density drop means that three of six teams are less likely to use the 
network's potential. According to the results obtained in this study, the needs specified by students (products or services) influenced the obtained result. Some of them were difficult to implement in a given situation. In such cases, there is a need to conduct research on micro- and meso- levels using the SNA method [Martin, Wellman 2011; Borgatti, Lopez-Kidwell 2011].

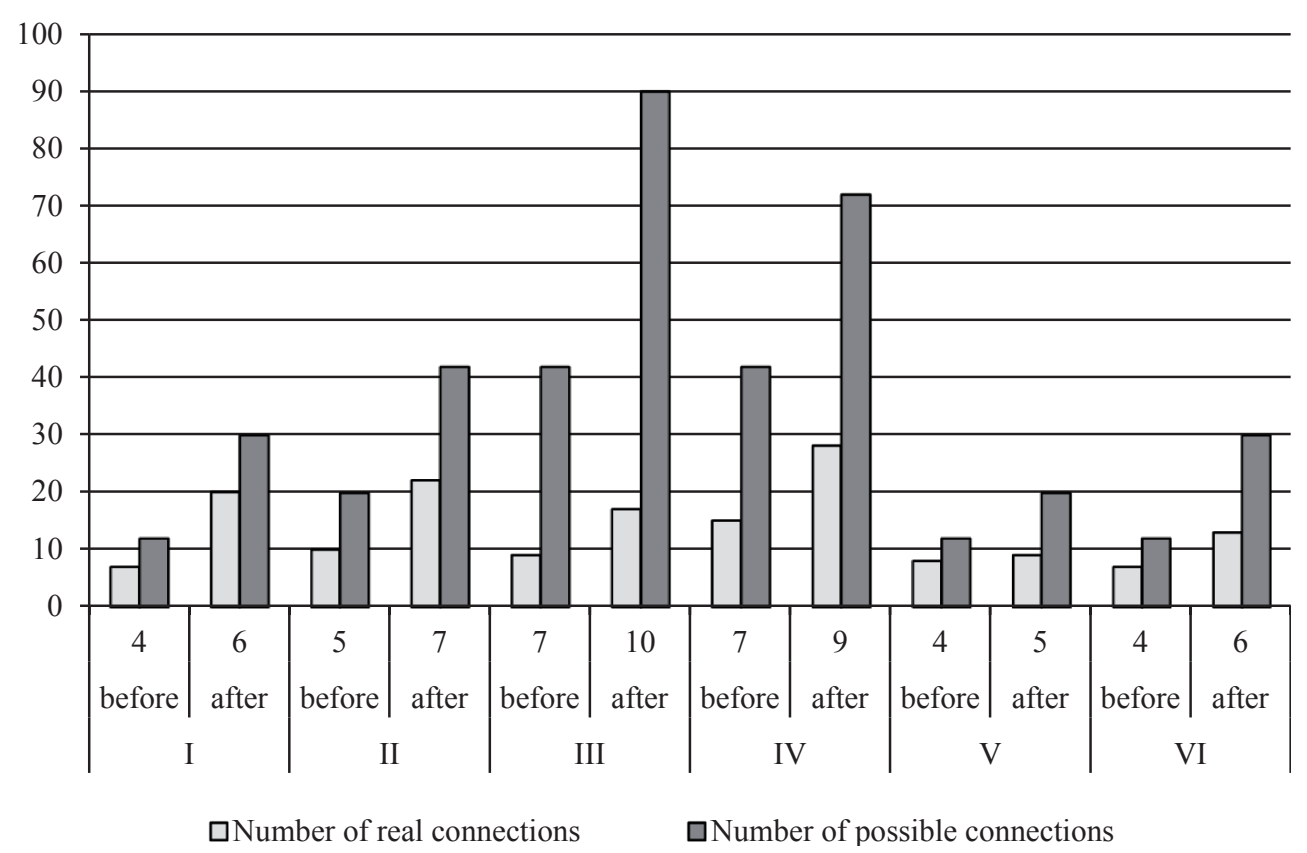

Fig. 5. Results of the experiment - the results of six teams (I-VI)

Source: own study.

4. In each team the number of real connections increased with the number of participants (Fig. 5) and was between $n^{2}$ and $n * \log (n)$ (Fig. 3). The experiment made it possible to verify that with the inclusion of more people. The value of the entire network increases, as well as the value of each unit individually.

\section{Conclusions}

Social network analysis is the methodology for identifying patterns and relationships in a social network. It is intended to enable to understand patterns of interactions taking place in networks.

Network analysis can be used in a variety of areas: logistics, medicine, change management (mergers and acquisitions), knowledge management, project management, communication, librarianship, police, marketing, information technology, 
social network contact analysis at various levels of company management (inside the company, through external relations, to inter-organizational management). Network analysis can help to improve communications in an organization and organizational effectiveness. It allows to identify barriers in the flow of knowledge, discover invisible structures and relationships, analyse quantitative and qualitative data.

The exercise that students conducted should show them the potential that social networks have and familiarize them with Metcalfe's and Reed's law. Students examined that the "network effect" occurs when a product or service gains in value. And it occurs when the number of users increases, which in turn happens, when they can receive or deliver the product or service.

Teaching about networks has a huge future ahead, as Miller and Christakis [2011] have already said. Social contacts have always allowed the flow of knowledge that can be used to stimulate cooperation between students or employees, to find informal leadership in organizations or to identify key customers (targeting). Social Network Analysis allows to rediscover the already known phenomena. Using the SNA method we can for instance: analyse airlines, transport connections, material flow in logistics and also relations in student groups and connections between these groups. In addition, the SNA method allows us to study network changes over time.

\section{References}

Beckström R., 2008, The Economics of Networks and Cybersecurity, NCSC, https://www.unibw.de/ infosecur/publications/conference_presentations/beckstroem_economics_presentation_2008 (access: December 2017).

Borgatti S.P., Lopez-Kidwell V., 2011, Network Theory, [in:] The SAGE Handbook of Social Network Analysis, J. Scott and P.J. Carrington (eds.), London.

Briscoe B., Odlyzko A., Tilly B., 2006, Metcalfe's law is wrong, IEEE Spectrum, no. 43(7), pp. 34-39, http://spectrum.ieee.org/jul06/4109 (access: December 2017).

Cross R., Liedtka J., Weiss L., 2005, A practical guide to social networks, Harvard Business Review, March, p. 124.

Czakon W., 2009, Koopetycja - splot tworzenia i zawłaszczania wartości, Przegląd Organizacji, no. 12 , pp. 11-14.

Czetwertyński S., 2013, Możliwości poznawcze prawa Metcalfe 'a w określeniu wartości ekonomicznej sieci komunikacyjnych, Prace Naukowe Uniwersytetu Ekonomicznego we Wrocławiu no. 305, pp. 108-117.

Ehrlich K., Carboni I., 2005, Inside Social Network Analysis, IBM Technical Report, http:/www.watson.

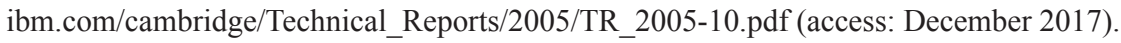

Evans D., 2010, Social Media Marketing: An Hour a Day, John Wiley \& Sons, Hoboken.

Furht B. (ed.), 2010, Handbook of Social Network Technologies and Applications, Springer Science \& Business Media.

Kemper A., 2010, Valuation of Network Effects in Software markets. A complex Networks Approach, Spronger-Verlag, Berlin-Heidelberg.

Klimas P., 2015, Przesłanki i bariery zawiązywania więzi międzyorganizacyjnych, Problemy Zarządzania, vol. 13, no. 1(5), t. 1 . 
Martin A., Wellman B., 2011, Social Network Analysis: An Introduction, J. Scott and P. J. Carrington (eds.), The SAGE Handbook of Social Network Analysis, London.

Martino F., Spoto A., 2006, Social Network Analysis: A brief theoretical review and further perspectives in the study of Information Technology, PsychNology Journal, no. 4(1), pp. 53-86.

Metcalfe R., 2006, Metcalfe's Law Recurses Down the Long Tail of Social Networks, http://vcmike. wordpress.com/2006/08/18/metcalfe-social-networks (access: December 2017).

Miller L., Christakis N., 2011, Tapping the Power of Social Networks, Harvard Business Review, https://hbr.org/2011/09/tapping-the-power-of-social-networks (access: November 2017).

Owyang J., Li Ch., Tran Ch., Jones A., 2010, Report: Career Path of the Corporate Social Strategist: Be Proactive or Become Social Media Help Desk, Altimeter, http://www.web-strategist.com/blog/ research/ (access: April 2017).

Pentland "Sandy" A., 2012, Nowe odkrycia na temat budowania doskonałych zespolów, Harvard Business Review, October, pp. 58-67.

Shih C., 2012, Era Facebooka, Helion, Gliwice.

Stokalski B., 2007, Sieć nieformalnych relacji - klucz do poprawy efektywności w firmach pracujacych systemem projektowym, Harvard Business Review Polska, September, pp. 52-66.

Unold J., 2011, Wykorzystanie efektu sieciowego w rozwoju społeczności wirtualnej, Zeszyty naukowe Uniwersytetu Szczecińskiego no. 656. Studia Informatica no. 28, pp. 101-112.

Van Howe L., 2014, Metcalfe's law: not so wrong after all, NETNOMICS: Economic Research and Electronic Networking, no. 15, pp. 1-8. 